\title{
Distribution and abundance of Euphausia mucronata: development stages and its relationship with temperature and chlorophyll-a concentration
}

\author{
Pamela González $^{1}(\mathbb{D})$, Armando Mujica ${ }^{1}(\mathbb{D})$ \& María Luisa Nava ${ }^{1}(\mathbb{D}$ \\ ${ }^{1}$ Departamento de Acuicultura, Universidad Católica del Norte, Coquimbo, Chile \\ Corresponding author: Armando Mujica (amujica@ucn.cl)
}

\begin{abstract}
Euphausia mucronata abundance and distribution of the developmental stages (calyptopis, furciliae, juveniles, and adults) was analyzed as a function of seawater temperature and chlorophyll- $a$ concentration between Paposo $\left(25^{\circ} \mathrm{S}\right)$ and Coquimbo $\left(30^{\circ} \mathrm{S}\right)$, Chile. Zooplankton samples were obtained using bongo nets during February of three consecutive years (2014-2016). The $Q$ coefficient was used to explore the relationship between the distribution and abundance of the development stages of $E$. mucronata with the temperature recorded throughout the water column. The adults were considerably more abundant than the rest of the ontogenetic development stages during the study period. The abundance of adults decreased from February 2014 to 2016, having a negative correlation with temperature. Relative abundance of juveniles and larvae increased positively related to the total euphausiid abundance. The $Q$ coefficient showed a significant association of all development states concerning the low-temperature intervals recorded throughout the seawater column. $Q$ coefficient showed no association with chlorophyll- $a$ concentration through the recorded intervals throughout the water column and neither with the vertical abundance and distribution of E. mucronata specimens.
\end{abstract}

Keywords: Euphausia mucronata; development stages; chlorophyll- $a$; $Q$ coefficient; Humboldt Current System; southeastern Pacific

\section{INTRODUCTION}

Chile's central northern coastline $\left(18 \sim 40^{\circ} \mathrm{S}\right)$ is relatively a straight line strongly influenced by Humboldt Current System (HCS) dynamic that extends from $\sim 42^{\circ} \mathrm{S}$ to the Equator (Montecino et al. 2005, Thiel et al. 2007). The HCS has a complex coastal oceanographic characteristic with a predominantly poleward current direction that varies in intensity, width, depth, location, seasonally and interannually. HCS is typically cold due to periodical upwelling events that bring up subsurface seawater rich with nutrients near the surface (Thiel et al. 2007). El Niño (EN) event frequently causes considerable changes in HCS environmental conditions deepening the thermocline and increasing the Sea Surface Temperature (SST) and mean sea level decreasing primary productivity. Along the HCS dynamic ecosystem occur a latitudinal thermal cline that decreases from north to south (Farías \& Castro 2008,
Karstensen \& Ulloa 2009). Escribano et al. (2000) reported that HCS, like other continental Eastern Boundary Currents (EBC) systems, typically has high primary productivity. It allows a highly profitable fishery industry in Peru and Chile due to the dynamic and persistent upwelling that generates the increased production of zooplanktonic herbivores and omnivores in a regular mode.

Euphausia mucronata G.O. Sars, 1883 (Euphausiacea) is a holoplanktonic marine krill species in the center-south coastal region of Chile, numerically dominant in the euphausiid community structure (Linacre \& Palma 2004, Mujica \& Pavez 2008, Riquelme-Bugeño et al. 2012). E. mucronata is key species in the trophic network of the pelagic occurrence within HCS due to its mean high abundance and broad distribution (Riquelme-Bugeño et al. 2016). This krill species one of the most biomass prominent predatorprey between lower levels of phytoplanktonic produc-

Corresponding editor: Sergio Palma 
tion and the higher trophic levels of the HCS pelagic ecosystem (Antezana 1970, 2010). Linacre \& Palma (2004) reported the broad latitudinal neritic distribution of E. mucronata in the southeastern Pacific (10-39 ${ }^{\circ}$ S), but sometimes this species can be collected up to $46^{\circ} \mathrm{S}$ (Antezana 2010, Riquelme-Bugeño et al. 2012).

E. mucronata daily vertical migration (DVM) is a relevant part of the biological pump moving biomass throughout the shallow oxygen minimum zone (OMZ) of the HCS (Antezana 2009). Riquelme-Bugeño et al. (2012) concluded that the euroic characteristics of $E$. mucronata allow it to withstand and adapt to the environmental changes caused by the El Niño and the upwelling dynamic. Riquelme-Bugeño et al. (2012) argue that nauplius, calyptopis, and early furcilia larvae stages do not migrate vertically.

The broad distribution of adults in the highly dynamic environmental conditions where they live brings up the question of the absence of daily vertical migration of the early developmental stages of the species. It may point to the issue that the horizontal distribution of the larvae could be closely related to sea temperature and chlorophyll- $a$ concentration (Chl- $a$ ). Thus, the present investigation explores the spatial relationship of E. mucronata with sea temperature and Chl- $a$ concentration during three consecutive summers (2014-2016), including the influence of a strong El Niño event 2015-2016 (NOAA 2019).

The goal of the present study was to relate the abundance and distribution of E. mucronata with temperature and chlorophyll- $a$ spatial and interannual variability.

\section{MATERIALS AND METHODS}

Zooplankton samples were collected along three crossshelf transects (Paposo, $25^{\circ} 00^{\prime} \mathrm{S}$; Caleta del Medio, $27^{\circ} 40^{\prime} \mathrm{S}$, and Coquimbo, $30^{\circ} 00^{\prime} \mathrm{S}$ ) with four oceanographic stations located at $1,5,10$, and $20 \mathrm{~nm}$ (nautical miles) off the coast. This zooplankton sampling effort was part of the research project "Hydroacoustic evaluation of anchovy recruitment between the III and IV Regions" surveyed in the central northern coast of Chile $\left(25-31.5^{\circ} \mathrm{S}\right)$ in February for three consecutive years (2014-2016) (Fig. 1).

The latitudinal thermal cline recorded along the coastal zone of the north-central region of Chile included February under El Niño 2015-2016 with positive anomalies in reference to available time-series information (NOAA 2019). The selected time series had exclusively oceanographic stations sampled during nighttime to decrease abundance biases due to the daily vertical migration of E. mucronata.

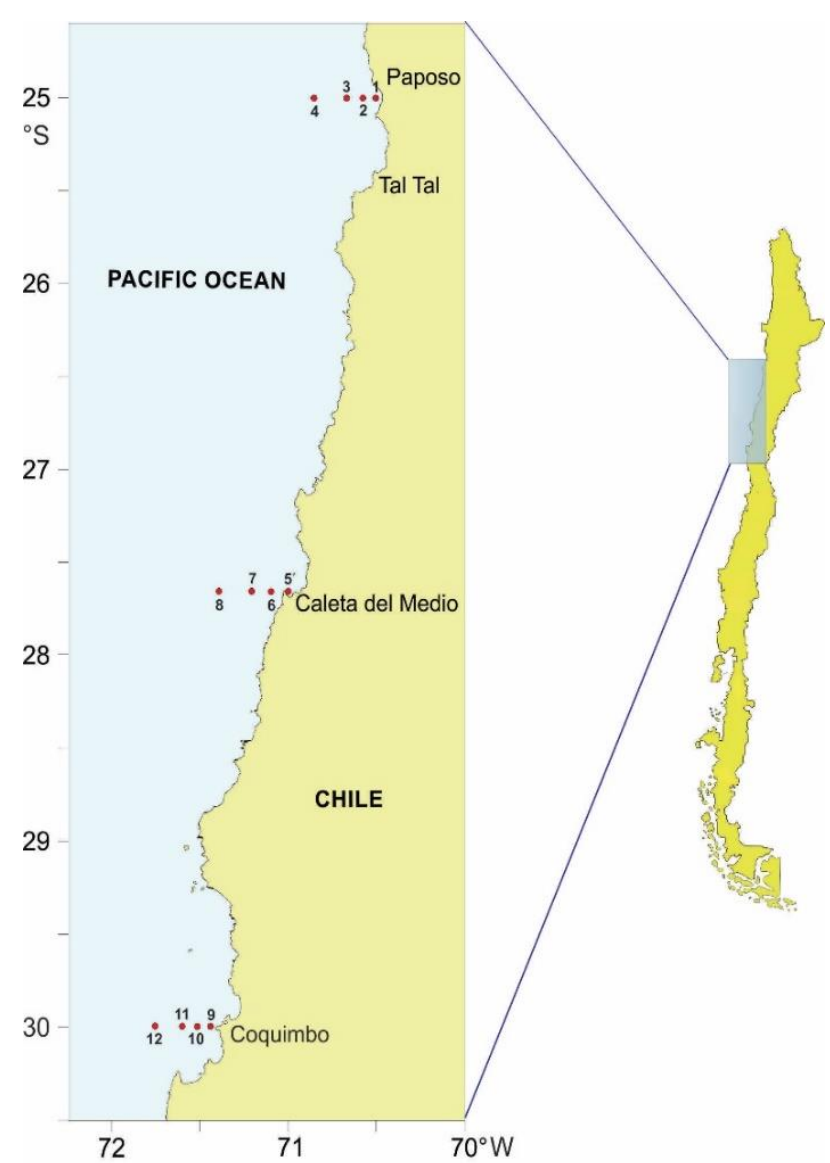

Figure 1. Location of cross-shelf oceanographic stations (•) sampled during February 2014, 2015, and 2016 along the central coast of Chile.

Zooplankton samples were collected onboard the $\mathrm{R} / \mathrm{V}$ Abate Molina using a $59 \mathrm{~cm}$ diameter bongo net equipped with a $300 \mu \mathrm{m}$ mesh net and each net with a TSK flowmeter. The Bongo net was towed vertically from $60 \mathrm{~m}$ depth to the sea surface in locations with seafloors $>60 \mathrm{~m}$ depth or $10 \mathrm{~m}$ above the sea bottom to the surface in locations with $<60 \mathrm{~m}$ of depth. $E$. mucronata were sorted out from the entire zooplankton samples (no aliquot), then counted the number of specimens for each developmental stage per sampled station (calyptopis, furciliae, juveniles, and adults).

Satellite SST and Chl- $a$ images were obtained for the area of study during February 2014, 2015, and 2016 from the oceanographic information obtained from the ERDDAP scientific database [http://coastwatch.pfeg. noaa.gov/erddap/ griddap/index.html page $=1 \&$ items per page $=1000]$ to visualize distribution patterns and compare with data recorded in situ.

The weighted average of the temperature and Chl- $a$ of the water column $(0-50 \mathrm{~m})$ was calculated from the data recorded in the oceanographic surveys mentioned above. 

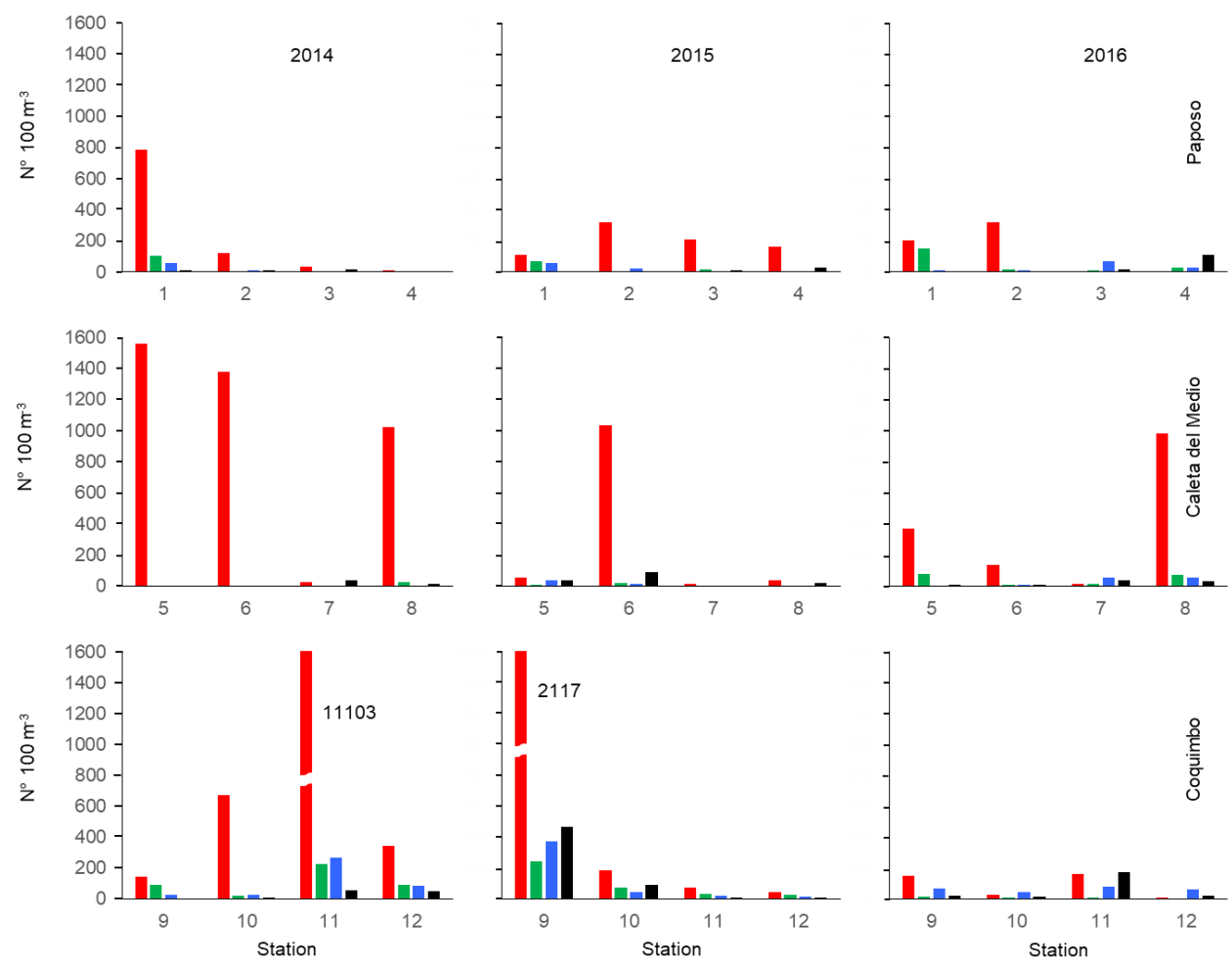

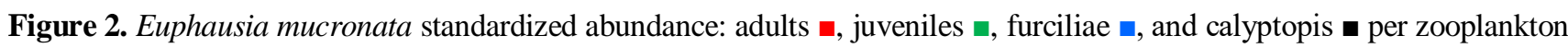
sampling stations collected during February 2014, 2015, and 2016 at the central coast of Chile.

The $Q$ coefficient (Kendall \& Gibbons 1990) was calculated to establish the relationships between $E$. mucronata abundance and distribution with the temperature and Chl- $a$ concentration. The $Q$ coefficient associates the abundance and frequency of occurrence for each development stage with the ranges of the environmental variables observed in situ. The $Q$ coefficient was calculated using the following expression:

$$
Q=\frac{\left(n^{\circ} E_{r} \times 100\right) / n^{\circ} E_{t}}{\left(n^{\circ} e s t_{r} \times 100\right) / n^{\circ} e s t_{t}}
$$

where, $n^{\circ} E_{r}$ : number of specimens of each developmental stage in each temperature or Chl- $a$ concentration interval, $n^{\circ} E_{i}$ : total number of specimens of each development stage; $n^{\circ} e t_{r}$ : number of stations in which each development stage is present in the interval; and $n^{\circ}$ est $t_{t}$ total number of stations. Where $Q$ coefficient values are greater than 1 indicate association of the development stage with the temperature or Chl- $a$.

\section{RESULTS}

Euphausia mucronata were found in all the collected zooplankton samples, recorded with a broad range of standardized abundance (13-11649 ind. $100 \mathrm{~m}^{-3}$ ) varying cross-shelf, latitudinally, and interannually. Adults were more abundant than the other ontogenetic development stages in most cruises (Fig. 2). The largest adult abundance was observed during February 2014 at the zooplankton station located $10 \mathrm{~nm}$ from the coast of Coquimbo (Sta. 11; 11103 ind $100 \mathrm{~m}^{-3}$ ) and February 2015 at zooplankton station located $1 \mathrm{~nm}$ from the same transect (Sta. 9; 2171 ind $100 \mathrm{~m}^{-3}$ ). The lowest adult abundances $\left(<10\right.$ ind $\left.100 \mathrm{~m}^{-3}\right)$ were obtained during February 2016 in the offshore stations for the northernmost and southernmost transects of the study area. The highest juvenile abundance (225-243 ind $100 \mathrm{~m}^{-3}$ ) was observed in the same stations that the highest abundance of adults in 2014 and 2015. The highest abundance during 2016 (Sta. 1; 148 ind $100 \mathrm{~m}^{-3}$ ) was obtained from the oceanographic station located $1 \mathrm{~nm}$ off the coast for the northernmost transect (Fig. 2). Furcilia larvae, like juveniles and adults, had their highest abundance the same stations during 2014 (Sta. 11) and 2015 (Sta. 9). The highest abundances of calyptopis larvae were collected during February 2015 at the station located $1 \mathrm{~nm}$ off the Coquimbo coast (Sta. 9; 464 ind $100 \mathrm{~m}^{-3}$ ).

E. mucronata abundance increased latitudinally from north to south during February 2014 and 2015, decreasing interannually from February 2014 to 2016. 
Table 1. Abundance, dominance, and frequency of Euphausia mucronata per development stages collected during February 2014-2016 and per sampling transect. North: Paposo, central: Caleta del Medio, south: Coquimbo.

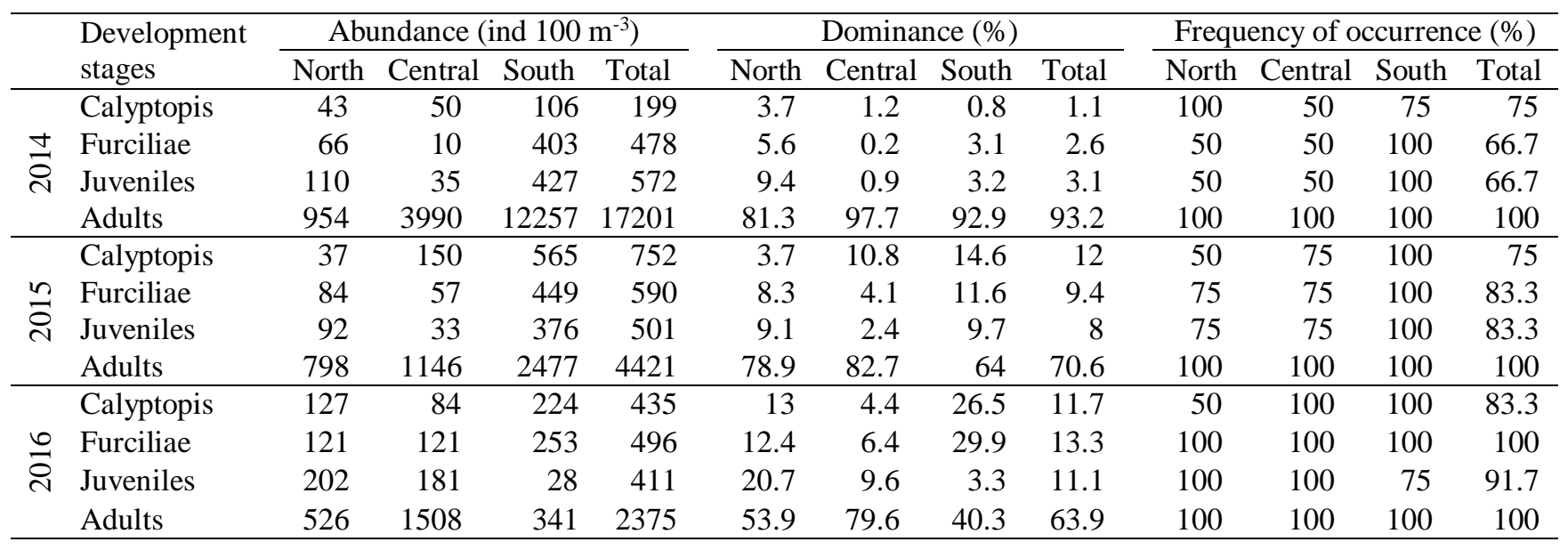

The notorious high abundance of adults strongly influenced this trend compared to the other development stages (Table 1).

The numerical dominance of adults was higher in the central transect (Caleta del Medio) for the three years than the other two transects (Paposo and Coquimbo). Adults always accounted for $>40 \%$ of total abundance, but their numerical dominance decreased interannually from 2014 to 2016 . The distribution of juvenile abundance was heterogeneous in time and space. At the same time, the total numerical dominance increased markedly and progressively from 2014 and 2016 , its frequency of occurrence also progressively increased for those years (Table 1). The abundance of furcilia larvae was always higher in the southern transect, while the total dominance and frequency of occurrence increased markedly from February 2014 to 2016 (Table 1). The abundance of the calyptopis larvae generally increased from north to south, having maximum abundances in February 2015, with markedly lower abundance in February 2014. Although the abundance of adults increased from north to south, and their numerical dominance decreased from 2014 to 2016, the dominance of the other development stages increased from February 2014 to 2016.

In February, the sea surface temperature ranged between $14.7-20.6^{\circ} \mathrm{C}$ in $2014,15.3-21.2^{\circ} \mathrm{C}$ in 2015 , and $17.3-22.9^{\circ} \mathrm{C}$ in 2016 (Fig. 3). The weighted average of seawater column temperature $(0-50 \mathrm{~m})$ recorded in February ranged between $12.6-17.5^{\circ} \mathrm{C}$ in $2014,12.2$ $16.8^{\circ} \mathrm{C}$ in 2015 , and $13.8-17.6^{\circ} \mathrm{C}$ in 2016 (Fig. 3). In the February periods, the sea surface temperature decreased progressively from north to south and east to west. It increased SST from February 2014 to 2016
(Fig. 4), a trend that was also found in the weighted average of the water column (Fig. 3).

The sea surface Chl- $a$ concentrations and the weighted average of Chl- $a$ concentrations through the water column did not have a clear distribution pattern with the highest concentrations in the stations located at $1 \mathrm{~nm}$ from the coast (3.5-4.9 $\left.\mu \mathrm{g} \mathrm{L}^{-1}\right)$, station 9 in 2014, and station 5 in 2016 (Fig. 5). The Chl- $a$ weighted average concentration of the water column was heterogeneous. With high values in the station located $1 \mathrm{~nm}$ off the coast of the northern transect in February $2014\left(6.9 \mu \mathrm{g} \mathrm{L}^{-1}\right)$, which widely exceeds the surface concentration because it is the subsurface peak (Fig. 5), a product of the unusual value of 10.0 at $20 \mathrm{~m}$ and $17.7 \mu \mathrm{g} \mathrm{Chl}-a \mathrm{~L}^{-1}$ at $30 \mathrm{~m}$ depth.

The $Q$ coefficient obtained between the distribution and abundance of the four developmental stages of $E$. mucronata and the SST showed an inverse relationship with abundance. The adult's $Q$ coefficient had the highest values in the lower range of surface temperature $\left(<17^{\circ} \mathrm{C}\right)$. For calyptopis, furciliae and juveniles had higher values with the temperature range of $17.1-19^{\circ} \mathrm{C}$. However, furciliae and juveniles had a higher $Q$ coefficient $>1$ in the lower range $\left(<17^{\circ} \mathrm{C}\right)$ and also caliptopis in the upper range $\left(>21^{\circ} \mathrm{C}\right)$ (Table 2).

$Q$ coefficient applied to the weighted average ranges of the seawater column temperature allowed us to infer that all the development stages were associated with the lower temperatures (Table 3).

According to the $Q$ coefficient values obtained from the relationship established between the distribution and abundance of E. mucronata development stages with sea surface Chl- $a$ concentration ranges, only adults associated with the 1-4 sea surface Chl- $a$ range (Table 4). 

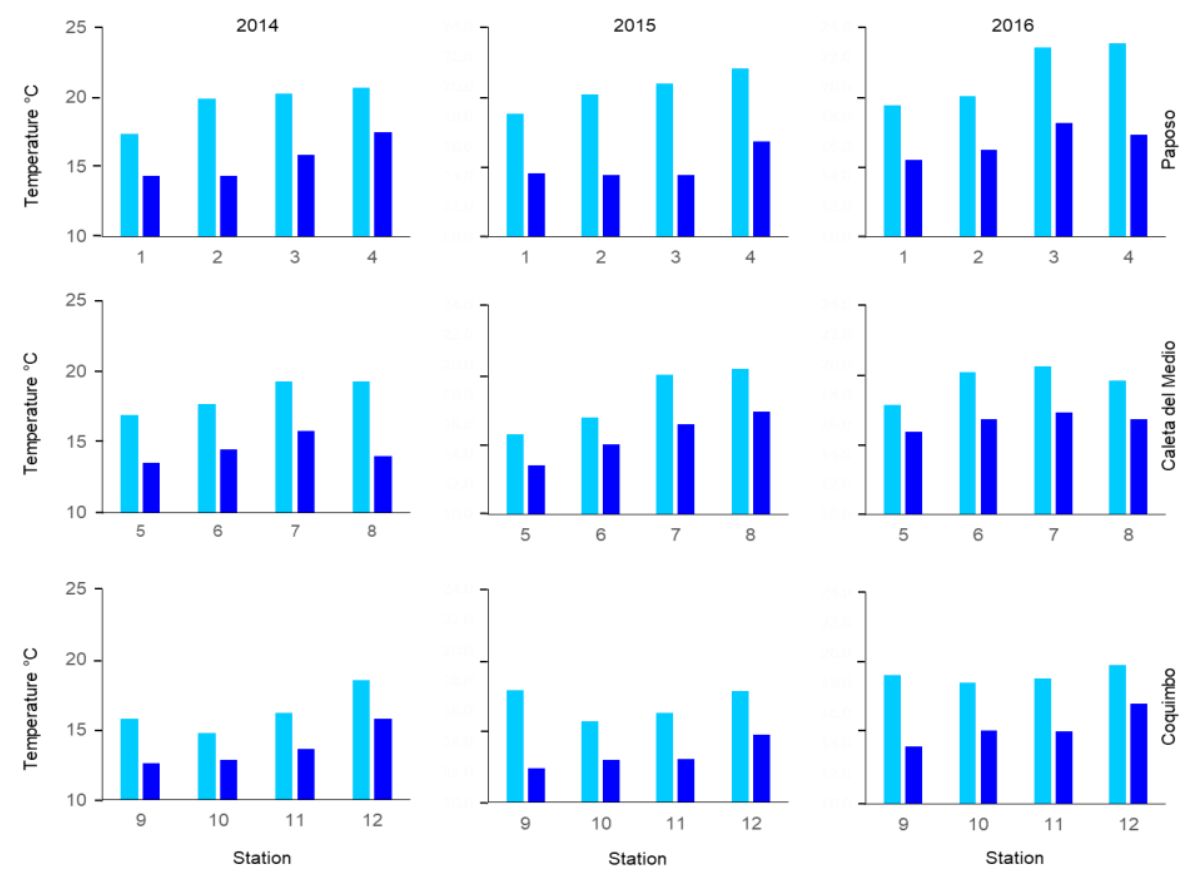

Figure 3. Sea surface temperature $\left({ }^{\circ} \mathrm{C}\right) \backsim$ and the water column weighted average $(0-50 \mathrm{~m}) \backsim$ recorded at sampling stations during February 2014, 2015, and 2016 at the central coast of Chile.

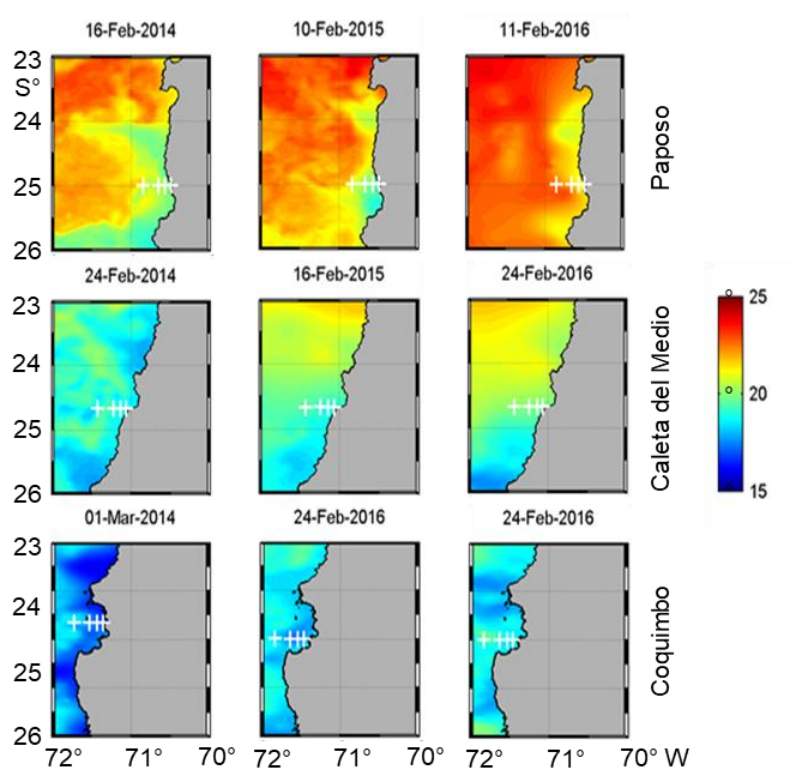

Figure 4. Satellite sea surface temperature $\left({ }^{\circ} \mathrm{C}\right)$ images recorded during the three sampled transects during February 2014, 2015, and 2016.

The $Q$ coefficient applied to the Chl- $a$ concentration weighted average in the water column showed that only adults were associated with the highest and lowest Chl- $a$ concentrations (Table 4), suggesting that the Chl- $a$ concentration would not influence the distribution and abundance of E. mucronata.

\section{DISCUSSION}

The broad distribution of Euphausia mucronata in the study area during February 2014-2016 corroborate previous reports that consider this species as a key species of the HCS ecosystem, numerically dominant among euphausiids and with relevant biomasses in zooplankton (Antezana 1978, 2002, 2010, Linacre \& Palma 2004, Antezana \& Melo 2008, RiquelmeBugueño et al. 2012, 2013, 2016).

The abundance decrease of $E$. mucronata in February from 2014 to 2016 corresponds to an increase in the region's thermal condition (NOAA 2019). Sea surface temperature anomalies of the intertropical region recorded during February 2014 correspond to neutral ENSO conditions (Leiva et al. 2014). In February 2015 began a warm El Niño event initially with weak intensity (Leiva et al. 2015). In 2016, the regional ENSO monitoring indicators showed the warming continuity, considered a strong intensity of El Niño in summer 2016 (Saavedra et al. 2016).

The progressive latitudinal increase in the abundance of adults of $E$. mucronata coincides with the decrease in temperature; it is a trend previously reported for this species in coastal areas of the HCS (Mujica \& Pavez 2008). Fernández et al. (2002) found in the Mejillones area $\left(23^{\circ} \mathrm{S}\right)$ an inverse relationship between adults abundance and temperature (El Niño $v s$. 

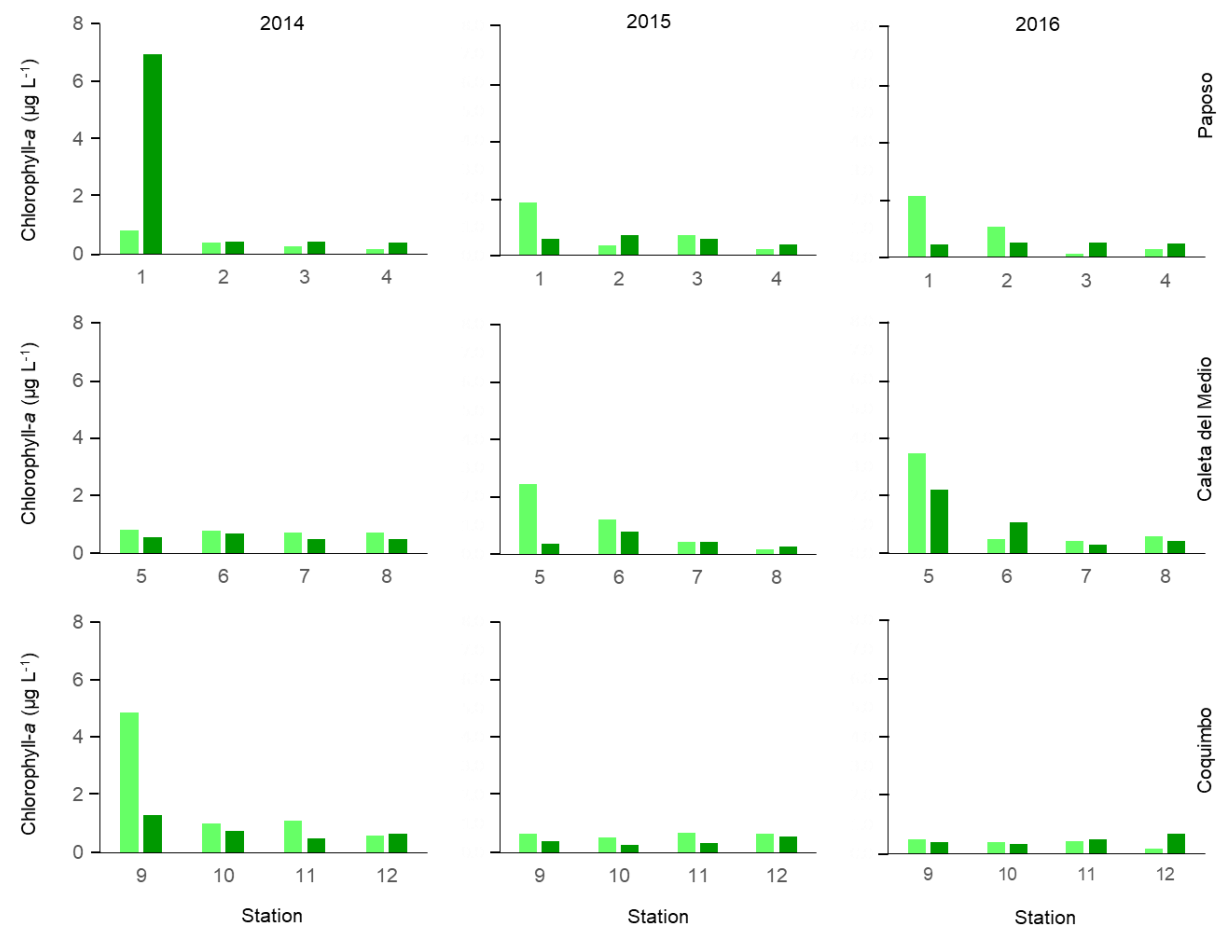

Figure 5. Surface Chl- $a$ concentration $\left(\mu \mathrm{g}\right.$ Chl- $\left.a \mathrm{~L}^{-1}\right) \backsim$ and water column weighted Chl- $a$ average $(0-50 \mathrm{~m}) \backsim$ in sampling stations recorded during February 2014, 2015, and 2016.

Table 2. $Q$ coefficient values of Euphausia mucronata per development stages as a function of sea surface temperature ranges. $Q$ coefficient values $>1$ indicate an association of the abundance of a particular development stage with the temperature (higher values of $Q$ coefficient are in bold).

\begin{tabular}{lcccc}
\hline \multirow{2}{*}{$\begin{array}{l}\text { Development } \\
\text { stages }\end{array}$} & \multicolumn{4}{c}{ Sea surface temperature intervals $\left({ }^{\circ} \mathrm{C}\right)$} \\
\cline { 2 - 5 } & Interval & Interval & Interval & Interval \\
& $<17$ & $17.1-19$ & $19.1-21$ & $>21$ \\
\hline Calyptopis & 0.9 & $\mathbf{1 . 6 9}$ & 0.35 & 1.34 \\
Furciliae & 1.25 & $\mathbf{1 . 6 3}$ & 0.31 & 0.77 \\
Juveniles & 1.43 & $\mathbf{1 . 7 6}$ & 0.19 & 0.31 \\
Adults & $\mathbf{2 . 7 8}$ & 0.84 & 0.26 & 0.09 \\
\hline
\end{tabular}

Table 3. $Q$ coefficient values of Euphausia mucronata development stages with weighted average ranges of the water column temperature $(0-50 \mathrm{~m}) . Q$ coefficient values $>1$ indicate the association of abundance of a particular development stages with temperature (higher values of $Q$ coefficient are in bold).

\begin{tabular}{lccl}
\hline \multirow{2}{*}{$\begin{array}{l}\text { Development } \\
\text { stages }\end{array}$} & \multicolumn{3}{c}{$\begin{array}{c}\text { Water column temperature } \\
\text { intervals }\left({ }^{\circ} \mathrm{C}\right)\end{array}$} \\
\cline { 2 - 4 } & Interval & Interval & Interval \\
& $12-14$ & $14.1-16$ & $16.1-18$ \\
\hline Calyptopis & $\mathbf{1 . 7 7}$ & 0.04 & 0.05 \\
Furciliae & $\mathbf{1 . 9 8}$ & 0.04 & 0.05 \\
Juveniles & $\mathbf{1 . 7 9}$ & 0.05 & 0.02 \\
Adults & $\mathbf{2 . 5 7}$ & 0.49 & 0.23 \\
\hline
\end{tabular}

non-El Niño), as also was associate the presence of $E$. mucronata with cold coastal waters in northern Peru (Orosco \& Ayón 2015).

The significant predominance of adults over the other development stages would be a consequence of the sampling season (austral summer) and also likely the Bongo net sampling bias. Fernández et al. (2002), based on metanauplii and calyptopis presence in northern Chile $\left(23^{\circ} \mathrm{S}\right)$, suggest that E. mucronata reproduce throughout the year intensification during spring. The generational time of E. mucronata is still unknown. Riquelme-Bugueño et al. (2012) also found the highest concentrations of eggs and early development stages of $E$. mucronata during early spring in Chile's south-central zone (30-45 $\mathrm{S})$. Orosco \& Ayón 
Table 4. $Q$ coefficient values of Euphausia mucronata development stages with sea surface chlorophyll- $a$ ranges and weighted average in the water column $(0-50 \mathrm{~m}) . Q$ coefficient values $>1$ indicate association of abundance of a particular of the development stage with the Chl- $a$ concentration (higher values of $Q$ coefficient are in bold).

\begin{tabular}{lccc}
\hline \multirow{2}{*}{$\begin{array}{l}\text { Development } \\
\text { stages }\end{array}$} & \multicolumn{3}{c}{ Sea surface Chl- $a$ intervals $\left(\mu \mathrm{g} \mathrm{L}^{-1}\right)$} \\
\cline { 2 - 4 } & Interval & Interval & Interval \\
& $<1$ & $1-4$ & $>4$ \\
\hline Calyptopis & 0.07 & 0.04 & 0.00 \\
Furciliae & 0.06 & 0.08 & 0.04 \\
Juveniles & 0.04 & 0.11 & 0.13 \\
Adults & 0.56 & $\mathbf{2 . 6 0}$ & 0.21 \\
\hline \multicolumn{4}{c}{ Chl- $a$ water column intervals $\left(\mu \mathrm{g} \mathrm{L}^{-1}\right)$} \\
\hline Calyptopis & 0.06 & 0.01 & 0.02 \\
Furciliae & 0.07 & 0.02 & 0.08 \\
Juveniles & 0.06 & 0.09 & 0.16 \\
Adults & 1.06 & 0.33 & $\mathbf{1 . 1 8}$ \\
\hline
\end{tabular}

(2015) found that more than $45 \%$ of the adults corresponded to E. mucronata. The calyptopis and furcilia larvae of the euphausiids had very low abundances during summer in northern Peru (20112012). Aronés \& Nakazaki (2019) also found in Peru waters that calyptopis and furcilia larvae represented the highest euphausiids abundances (66 and 31\%, respectively) during June 2015. These studies show that independent of latitudinal differences, the highest reproductive activity of $E$. mucronata would occur at the end of winter and spring, which would explain the low abundance of the early stages of development during summer (February 2014-2016).

The relationship established by the $Q$ coefficient between the different stages of development of the species and the surface temperatures and the water column indicates a clear preference for lower temperatures, as González et al. (2000) reported. Fernández et al. (2002) associated the highest concentrations of the species with cold waters recorded during non-El Niño periods.

Although euphausiids have been defined as opportunistic omnivores, they mainly feed on phytoplankton (Riquelme-Bugueño et al. 2020). Escribano et al. (2000) and Antezana (2010) have pointed out that $E$. mucronata is a key species in the HCS pelagic trophic web. It is one of the main energy transfers between basic levels of planktonic production and the upper levels of the pelagic ecosystem and being a neritic species associated with coastal upwelling areas (Riquelme-Bugueño et al. 2012).

Although previous studies show that the distribution and abundance of E. mucronata are usually associated with high primary production areas, occasionally diffe- rent E. mucronata development stages are found in regions with low Chl- $a$ concentrations. This weak relationship established with Chl- $a$ concentration (here analyzed using the $Q$ coefficient) can be explained by the behavior of E. mucronata and other euphausiids, which would exploit the upwelling edges, where upwelling fronts are formed and do not have the highest Chl- $a$ concentrations (Fernández et al. 2002).

Although E. mucronata is mainly phytoplanktophagous (Riquelme-Bugueño et al. 2020), this species can shift its trophic habits to carnivory when exposed to low diatom concentrations, like the opportunistic omnivory previously known for other euphausiid species (Mauchline \& Fisher 1969, Mauchline 1980, Pilditch \& McClatchie 1994).

\section{ACKNOWLEDGMENTS}

This study was funded by the project "Hydroacoustic evaluation of anchovy recruitment between the III and IV Regions," awarded by the Fondo de Investigación Pesquera y Acuicultura (FIPA). The authors also thank the support provided by the Instituto de Fomento Pesquero (IFOP) and Universidad Católica del Norte to obtain the information used in the first year of the present study. We thank the crew of the R/V Abate Molina and the personnel who aided in sample collection. Thanks, M.Sc. José Iván Sepúlveda for the translation and critical review of the document.

\section{REFERENCES}

Antezana, T. 1970. Eufáusidos de la costa de Chile, su rol en la economía del mar. Revista de Biología Marina y Oceanografía, Valparaíso, 14: 19-27.

Antezana, T. 1978. Distribution of euphausiids in the Chile-Peru Current with particular reference to the endemic Euphausia mucronata and the oxygen minima layer. Ph.D. Thesis, University of California, San Diego.

Antezana, T. 2002. Vertical distribution and diel migration of Euphausia mucronata in the minimum oxygen layer of the Humboldt Current. In: Färber-Lorda, J. (Ed.). Oceanography of the Eastern Pacific II. CICESE, Ensenada, pp. 13-28.

Antezana, T. 2009. Species-specific patterns of diel migration into the Oxygen Minimum Zone by euphausiids in the Humboldt Current Ecosystem. Progress in Oceanography, 83: 228-236.

Antezana, T. 2010. Euphausia mucronata: a keystone herbivore and prey of the Humboldt Current System. Deep-Sea Research II, 57: 652-662. 
Antezana, T. \& Melo, C. 2008. Desarrollo larvario de krill de la Corriente de Humboldt, Euphausia mucronata G.O. Sars, 1883 (Malacostraca, Euphausiacea). Crustaceana, 81: 305-328.

Aronés, K. \& Nakazaki, C. 2019. Ictioplancton y eufáusidos frente a la costa peruana durante el otoño 2015. Boletín Instituto del Mar del Perú, 34: 473-488.

Escribano, R., Marín, V. \& Iribarren, C. 2000. Distribución de Euphausia mucronata en el área de surgencia de la Península Mejillones, norte de Chile: influencia de la capa mínima de oxígeno. Scientia Marina, 64: 69-77.

Farías, M. \& Castro, C. 2008. Variabilidad de la temperatura superficial del mar, identificación de surgencias costeras y su relevancia en un área marina costera protegida del desierto de Atacama, Chile. Revista de Geografía Norte Grande, 41: 49-61.

Fernández, D., Escribano, R. \& Hidalgo, P. 2002. Distribución de eufáusidos en el sistema de surgencia frente a la península de Mejillones $\left(23^{\circ} \mathrm{S}\right)$ asociada a condiciones previas y durante El Niño 1997-1998. Investigaciones Marinas, Valparaíso, 30: 25-43.

González, H.E., Sobarzo, M., Figueroa, D. \& Nöthig, E.M. 2000. Composition, biomass and potential grazing impact of the crustacean and pelagic tunicates in the northern Humboldt Current area off Chile: differences between El Niño and non-El Niño years. Marine Ecology Progress Series, 195: 201-220.

Karstensen, J. \& Ulloa, O. 2009. The Peru-Chile Current System. In: Steele, J.H., Thorpe, S.A. \& Turekian, K.K. (Eds.). Encyclopedia of ocean sciences. Academic Press, London, pp. 385-392.

Kendall, M. \& Gibbons, J.D. 1990. Rank correlation methods. Oxford University Press, New York.

Leiva, F., Legua, J., Cifuentes, U., Giglio, S., Reyes, H., Pizarro, M., et al. 2014. Evaluación hidroacústica del reclutamiento de anchoveta en la III y IV Regiones, año 2014. Informe final FIP 2013-04. IFOP, Valparaíso.

Leiva, F., Legua, J., Cifuentes, U., Giglio, S., Reyes, H., Pizarro, M. et al. 2015. Evaluación hidroacústica del reclutamiento de anchoveta en la III y IV Regiones, año 2015. Informe final. Subsecretaría de EconomíaEMT, Instituto de Fomento Pesquero, Valparaíso.

Linacre, L. \& Palma, S. 2004. Variabilidad espacio-temporal de los eufáusidos frente a la costa de Concepción, Chile. Investigaciones Marinas, Valparaíso, 32: 19-32.

Mauchline, J. 1980. The biology of mysids and euphausiids. In: Blaxter, J.H.S., Russel, F.S. \& Yonge, M. (Eds.). Advances in Marine Biology. Vol. 18. Academic Press, London, pp. 373-623.

Mauchline, J. \& Fisher, L.R. 1969. The biology of euphausiids. In: Russel, F.S. \& Yonge, M. (Eds.). Advances in Marine Biology. Vol. 7. Academic Press, London.
Montecino, V., Strub, P.T., Chavez, F.P., Thomas, A.C., Tarazona, J. \& Baumgartner, T. 2005. Biophysical interactions off western South America. In: Robinson, A.R. \& Brink, K.H. (Eds.). The sea. Harvard University Press, Cambridge, pp. 329-390.

Mujica, A. \& Pavez, C. 2008. Eufáusidos de la zona central de Chile, Archipiélago Juan Fernández e Islas Desventuradas. Latin American Journal of Aquatic Research, 36: 283-300.

National Oceanic and Atmospheric Administration (NOAA). 2019. ENSO: recent evolution, current status, and predictions. National Weather Service. Climate Prediction Center. [https://www.cpc.ncep. noaa.gov/products/analysis_monitoring/la-nina/enso_ evolution-status-fcsts-web.pdf]. Reviewed: December 10, 2019.

Orosco, X. \& Ayón, P. 2015. Abundancia, frecuencia y distribución de eufáusidos frente a la costa norte del Perú. Revista de Ciencias, 11: 20-30.

Pilditch, C. \& McClatchie, S. 1994. Quantitative analysis of carnivory in the krill Nyctiphanes australis, with an examination of the effect of non-preferred phytoplankton alternative prey. Marine Ecology Progress Series, 107: 41-53.

Riquelme-Bugueño, R., Escribano, R. \& GómezGutiérrez, J. 2013. Somatic and molt production in Euphausia mucronata off central-southern Chile: the influence of coastal upwelling variability. Marine Ecology Progress Series, 476: 39-57.

Riquelme-Bugueño, R., Gómez-Gutiérrez, J., Escribano, R., Ruiz, P., Hidalgo, P. \& Schneider, W. 2016. First measurements of euphausiid growth rates in the northern Humboldt Current $\left(23^{\circ} \mathrm{S}\right)$. Revista de Biología Marina y Oceanografía, 51: 435-440.

Riquelme-Bugueño, R., Núñez, S., Jorquera, E., Valenzuela, L., Escribano, R. \& Hormazábal, S. 2012. The influence of upwelling variation on the spatially structured euphausiid community off central-southern Chile in 2007-2008. Progress in Oceanography, 9295: 146-165.

Riquelme-Bugueño, R., Pantoja-Gutiérrez, S., Jorquera, E., Anabalón, V., Srain, B. \& Schneider, W. 2020. Fatty acid composition in the endemic Humboldt Current krill, Euphausia mucronata (Crustacea, Euphausiacea) in relation to the phytoplankton community and oceanographic variability off Dichato coast in central Chile. Progress in Oceanography, 188: $1-11$.

Saavedra, A., Vargas, R., Lang, C., Cifuentes, U., Reyes, H., Grendi, C., et al. 2016. Evaluación hidroacústica de los stocks de anchoveta y sardina común entre la $\mathrm{V}$ y X Regiones, año 2016. Informe final. Subsecretaría 
de Economía-EMT, Instituto de Fomento Pesquero, Valparaíso.

Thiel, M., Macaya, E.C., Acuña, E., Arntz, W.E., Bastias, H., Brokordt, K., et al. 2007. The Humboldt Current System of northern and central Chile. Oceanographic processes, ecological interactions, and socioeconomic feedback. Oceanography and Marine Biology: An Annual Review, 45: 195-344.

Received: January 24, 2020; Accepted: June 10, 2021 